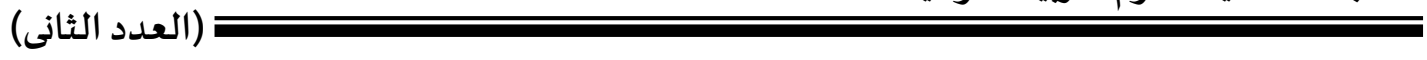

\title{
Investigation the effect of some seeds and their blend of liver physiological disorders using carbon tetrachloride (CCL4) on experimental animals
}

\author{
Khaled S. Shaheen ${ }^{(1)}$ and Wafaa A.Anwar ${ }^{(1)}$ \\ Nutrition and Food Science Dep., Faculty of Home Economics, Minufiya \\ University, Shebin El-Kom, Egypt.
}

\begin{abstract}
:
The present work was conducted to study the effect of different levels $(2.5 \%, 5 \%$, $7.5 \%)$ of flaxseed, plantain and their blend on liver, kidney function and blood lipid profile in CCL4- intoxicated rats. Forty four male albino rats weighing of $150 \pm 10 \mathrm{~g}$ were used and divided into eleven equal groups. One was kept as a control-ve group, while the other groups were treated by subcutaneous injection of carbon tetrachloride (CCL4) in paraffin oil 50\% V/V(2 $\mathrm{ml} / \mathrm{kg} \mathrm{B.Wt}$.) twice a week for two weeks to induce chronic damage of the liver. Body weight and food intake were recorded weekly. At the end of the experimental. All rats were weighted for calculation of body weight gain\%, feed efficiency ratio and blood serum samples were used for estimation of liver and heart functions.

Serum analysis showed a significant decrease in Cholesterol, Triglyceride and LDL in rat groups. While HDL was significantly increases in all rats groups comparing with control positive group and serum liver function were significantly decreases. The obtained results concluded that an improvement of all chemical analysis as compared to positive control group. Examination of liver sections of rats fed different diets (5\% flaxseed, $7.5 \%$ flaxseed, $7.5 \%$ plantain, 5\% mixture of all seeds and $7.5 \%$ mixture of all seeds) revealed no histopathological changes.
\end{abstract}

Key words: Flaxseed, plantain, rats, CCL4, liver, HDL, LDL cholesterol. 
دراسة تأثير بعض أنواع من البذور ومخلوطها على الخلل الحادث في الكبد باستخدام

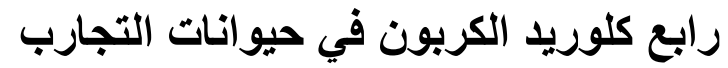

ا.د / خالد علي عبد الرحمن شاهين(') وفاء عبد الله أنور عامر (')

(') كلية الاقتصاد المنزلي- جامعة المنوفية - مصر "كر

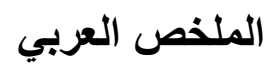

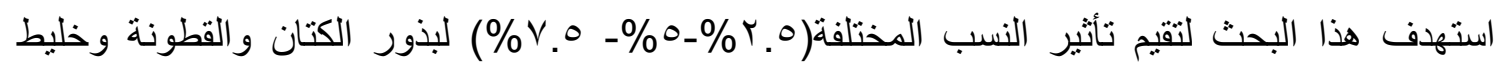

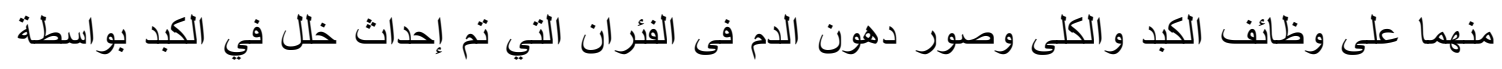

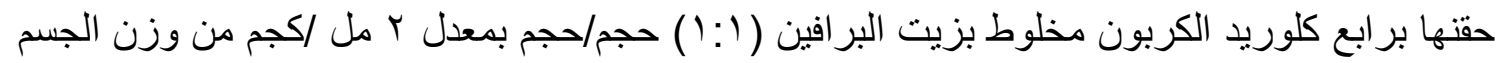

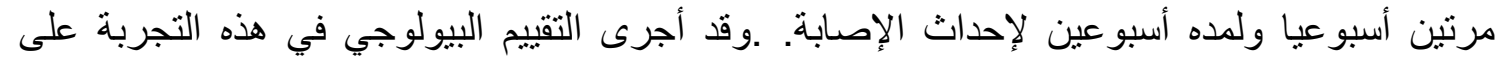

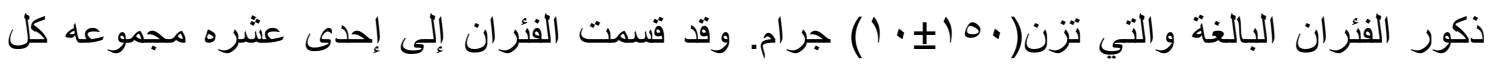

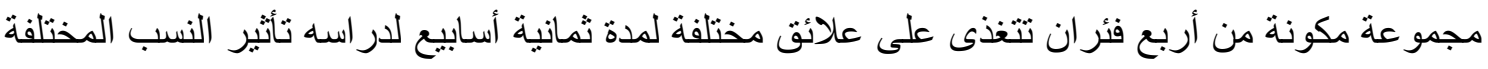
من البذور على تحسن وظائف الكبد.

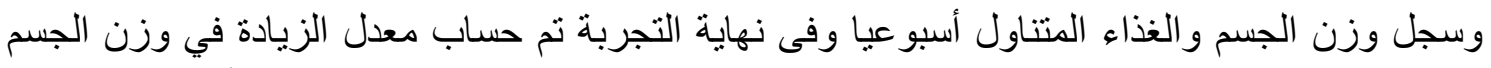

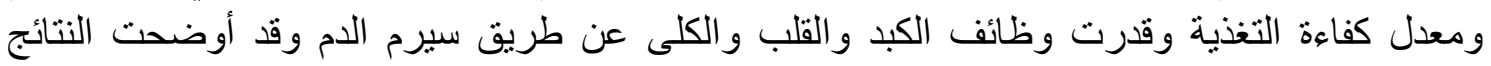

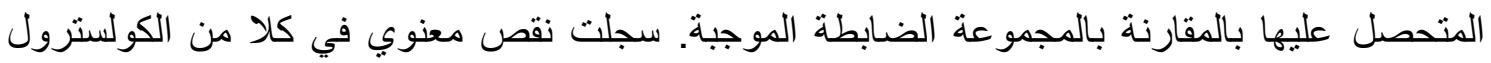

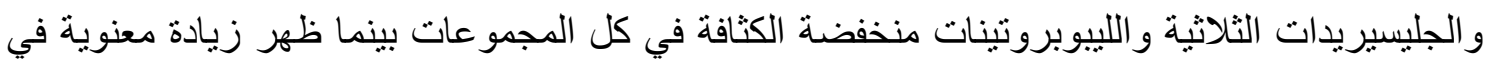

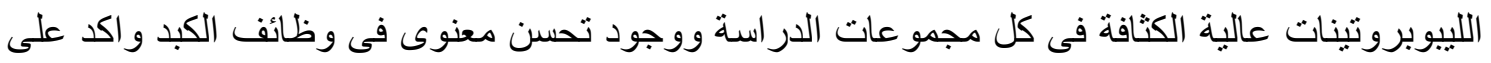

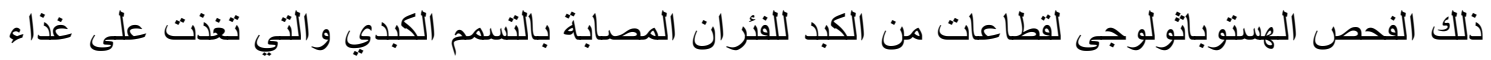

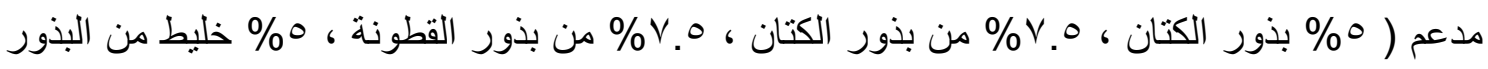

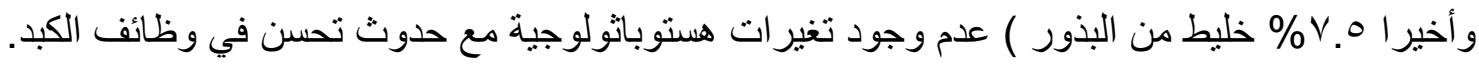

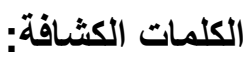

بذور الكتان- بذور القطونة- الفئران- رابع كلوريد الكربون- الكبد- بروتينات الدهون مرتفعة الكثافةبروتينات الدهون منخفضة الكثافة 


\section{Introduction}

The liver regulates many important metabolic functions. Hepatic injury is associated with distortion of these metabolic functions (Wolf, 1999). Additionally, it is the key organ of metabolism and excretion is continuously and variedly exposed to xenobiotics because of its strategic placement in the body. The toxins absorbed from the intestinal tract gain access first to the liver resulting in a variety of liver ailments. Thus liver diseases remain one of the serious heath problems. Modern medicines have little to offer for alleviation of hepatic diseases and it is chiefly the plant based preparations which are employed for their treatment of liver disorders. But there are not much drugs available for the treatment of liver disorders (Karan et al., 1999 and Chatterrjee, 2000).

Carbon tetrachloride (CCl4 ) is an extensively used industrial solvent, and it is the best-characterized animal model of xenobiotic-induced free radical-mediated hepatotoxicity (Reckngel and Glende, 1973). Carbon tetrachloride (CCl4 ), a potent hepatotoxic agent, is biotrandformed to a trichoromethyl radical by the cytochrome system in liver microsomes causing lipid peroxidation of membranes that leads to liver injury (Recknagel, 1983; Slater, 1984 and McCay etal., 1984).

Psyllium is the common name used for several members of the plant genus plantaago whose seeds are used commercially for the production of mucilage. The genus plantago contains over 200 species. P. ovata and P. psyllium are produced commercially in several European countries, the former Sovirt Union, Pakistan, and India. Plantago seed know commercially as black, French or Spanish psyllium is obtained from $P$. Psyllium and $P$. arenaria. Seed produced from $P$. ovata is known in trading circles as white or blonde psyllium, (Rocklin, 1996).

In vitro digestibility and digestibility of DM, apparent and true digestibility and NPR(in vivo) were also analyzed. Plantago seeds has $17.4 \%$ protein, $6.7 \%$ fat, $24.6 \%$ total dietary fiber, $19.6 \%$ insoluble fiber, $5.0 \%$ soluble fibre and a combustion heat of $4.75 \mathrm{Kcal} / \mathrm{g}$ Osborne fractionation (based on solubility albumin $35.8 \%$, globulin $23.9 \%$ and prolamin $11.7 \%$. The oil from plantago seeds had a high proportion of linolenic acid(6.9\%). In vitro protein digestibility of the plantago seed was $77.5 \%$, suggesting a highly digestible protein. Lysine content was $6.82 \mathrm{~g} / 100 \mathrm{~g}$ of protein, higher than wheat and oats (2.46 and 4.20 $\mathrm{g} / 100 \mathrm{~g}$ of protein, respectively). Rat bioassays showed values of $89.6 \%$ digestibility of DM, 86,0\% apparent digestibility, $88.1 \%$ true digestibility, and 4.40 corrected NPR. They concluded that plantago whole grain shows favorable nutritional quality when compared with cereals and legumes (Romero et al., 2006).

Flaxseed is the seed from the flax plant (linum usitatissimumL), which is a member of the Linaceae family. The plant is not a new crop being native to 


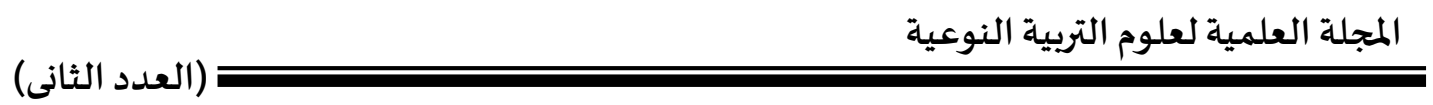

Weast Asia, and cultivated since at least $5000 \mathrm{BC}$; today it is mainly grown for its oil (Berglund, 2002).

Whole flaxseed (ground meal, powder or intact seed) contains $28 \%$ dietary fiber, (7-10\% soluble fiber, $11-18 \%$ insoluble fiber), $40 \%$ fat (73\% of it being polyunsaturated fatty acids), and $21 \%$ protein. Other flaxseed nutrients include vitamins $\mathrm{E}$ and $\mathrm{B}$, sterols, and mineral nutrients such as calcium, iron, and potassium. More than $50 \%$ of the fat in flaxseed is an essential fatty acid of omega-3 fatty acid group (alpha-linolenic acid, ALA), which makes flaxseed the richest plant source of omega-3 fatty acid. Flaxseed is rich in antioxidants, such as lignans (also a phytosterogen) and other phenolic molecules. Unlike the ground meal and powder, flaxseed oil contains no dietary fiber (Bloedon and Szapary, 2004).

\section{Materials and methods}

\section{Materials:}

Herbs: Plantago psyllium and flaxseeds (2013 year production) were obtained from Agricultural Research Center, Oil Crops Department,Giza,Egypt.

Carbon Tetra Chloride (CCl4 ): Carbon tetrachloride (CCl4) was obtained from El-Gomhoryia Company for Chemical Industries, Cairo, Egypt .It was dispensed in dark glass bottles each containing one liter as a toxic chemical material for liver poisoning according to (Passmore and Eastwood 1986). CCl4 is mixed with paraffin oil which obtained from the pharmacy for dilution during the induction.

\section{Animals :}

Forty four(44) (Sprague - Dawley strain) male albino rats, weighing (150 \pm 10 g) were used in this study from Rammed Research Station, Cairo University, Egypt. Rats were housed in wire cage under the normae laboratory condition and fed on basal diet for 7 consecutive days as adaptation period. Diets were introduced to rats in a special non - scattering feeding cup to avoid loss of food and contamination. Tap water was provided to rats by means of glass tubes projecting through wire cages from inverted bottles supported to one side of the cage.

\section{Animals and Experimental diet:}

Induction of Liver Intoxication in Rats: Forty(40) male albino rats (Sprague Dawley strain) weighing $(150 \pm 10 \mathrm{~g})$ were treated by subcutaneous injection of carbon tetrachloride (CCl4 ) in paraffin oil $50 \% \mathrm{~V} / \mathrm{V}(2 \mathrm{ml} / \mathrm{kg} \mathrm{B} . \mathrm{Wt}$.) twice a week for two weeks to induce chronic damage of the liver according to the method described by (Jayasekhar et al., 1997).

Experimental Designs and Animal Groups: Forty four(44) adult male albino rats, Sprague - Dawley strain, weighing $(150 \pm 10 \mathrm{~g})$ were used. All rats were fed 
standard diet for 7 consecutive days as adaptation period. Then, rats were distributed into11 groups each of 4 rats in which means of rats weight for all groups were nearly equal. All the groups of rats were housed in wire cages and fed on the experimental diet for 8 weeks according to the following groups:

Group 1: Control positive group (+ve), which $\mathrm{CCl} 4$ hepatotoxicity rats were fed on basal diet .

Group 2: Control negative group (-ve), which normal rats were fed on basal diet. Group 3 : hepatotoxicity rats were fed on $2.5 \%$ flaxseed .

Group $4:$ hepatotoxicity rats were fed on $5 \%$ flaxseed.

Group 5: hepatotoxicity rats were fed on $7.5 \%$ flaxseed.

Group 6: hepatotoxicity rats were fed on $2.5 \%$ plantago psyllium.

Group 7: hepatotoxicity rats were fed on 5\% plantago psyllium.

Group 8: hepatotoxicity rats were fed on $7.5 \%$ plantago psyllium weeks.

Group 9: $\mathrm{CCl} 4$ hepatotoxicity rats were fed on $2.5 \%$ Seeds mixture.

Group 10: hepatotoxicity rats were fed on 5\% Seeds mixture.

Group 11: hepatotoxicity rats were fed on $7.5 \%$ Seeds mixture.

\section{Methods:}

Biological evaluation of the different diets was carried out by determination of feed intake (consumption), body weight gain (BWG g/day) \& feed efficiency ratio (FER)according to Chapman et al., (1959).

At the end of the experiment period ( 4 weeks) the animal were fasted for $12 \mathrm{~h}$. Animals were anesthetized and blood sample were collected from the portal vein heparinzed centrifuge tubes. Plasma was separated by centrifugation at 3000 rpm for 10 minutes at room temperature and kept in plastic vial stored in the deep freezer at $\left(-20^{\circ} \mathrm{C}\right)$ until analyzed.

\section{Biochemical Analysis:}

Serum total cholesterol, triglyceride (TG) and high density liprotein cholesterol (HDLc) were determined by using enzymatic colorimetric methods of Allain, (1974), Fassati and Prencipe ( 1982), and Lopez ( 1977), respectively. The determination of low density lipoprotein cholesterol (LDLc) and very low density lipoprotein cholesterol (VLDLc) were carried out according to the method of Lee and Nieman (1996) as follows:

VLDL $(\mathrm{mg} / \mathrm{dl})=$ Triglycerides $/ 5$

$\mathrm{LDL}(\mathrm{mg} / \mathrm{dl})=$ Total cholesterol $-(\mathrm{HDL}+\mathrm{VLDL})$

Serum Aspartate and Alanine amino transferases (AST, ALT) and alkaline phosohatas (ALP) were determined by using enzymatic colorimetric methods Thefeld et al.,(1974) and Moss,( 1982), respectively.

Serum creatinin, Uric Acid and Enzymatic determination of serum urea were carried out according to the method of Henry, (1974), While et al., (1970), and Petton and Crouch, (1977) respectively. 


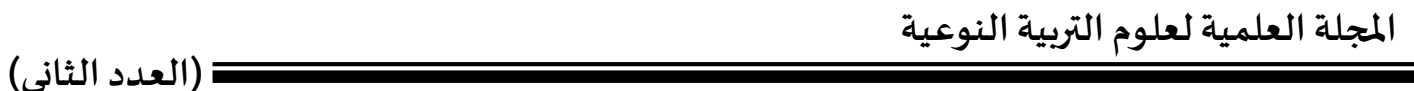

\section{Statistical Analysis:}

Statistical Analysis were Preformed using computer program statical package for social (SPSS) and compared with each other using the suitable tests ( Snedecor and Eochran,1980).

\section{RESULTS AND DISCCUTION}

Data present in Table (1) show the effect of feeding with different concentrations $(2.5 \%, 5 \%$ and $7.5 \%)$ of flaxseed, plantain and mixture of all seeds on food intake, body weight gain $\%$ and feed efficiency ratio in hepatotoxicity rats.

The mean value of food intake of control positive group was $18.12 \mathrm{~g}$ while the mean value of control negative group was $20.55 \mathrm{~g}$. The obtained results showed that there were non- significant differences compared to positive groups.

The same table showed the highest mean value of BWG\% was 25.7 for rats fed on control negative group. While the lowest mean value was $10.87 \mathrm{~g}$ and $12.76 \mathrm{~g}$ of control positive group and $7.5 \%$ plantain. However, feeding rats on $2.5 \%$ mixture of all seeds gave the highest values ( 17.17) as compared with the other treatments.

There were a significant increase in BWG\% among all tested groups as compared to positive group.

As For FER, the results showed that the mean value of all group were a non significantly differences among all tested groups as compared to positive groups except for rats feeding $2.5 \%$ flaxseed were significant $(\mathrm{p}<0.05)$ and $7.5 \%$ plantain were significant $(\mathrm{p}<0.01)$.

Table (2) illustrate the fasting serum lipids and the effect of feeding with different concentration $(2.5 \%, 5 \%$ and $7.5 \%)$ of flaxseed, plantain and mixture of all seeds on serum lipids in hepatotoxicity rats.

It could be observed that the groups of $7.5 \%$ flaxseed and $(5 \%, 7.5 \%)$ plantain were significant $(\mathrm{p}<0.05)$ and $7.5 \%$ plantain were significant $(\mathrm{p}<0.01)$. For TG the results showed that there were significant differences expect for $2.5 \%$ flaxseed and $2.5 \%$ mixture of all seeds as compared to positive groups.

As for HDL, the mean values of negative control was higher than that of positive control. While the mean values of groups fed on $7.5 \%$ flaxseed was more significantly higher than that of positive control.

Concerning LDL, the mean value of negative control was lower than that of positive control. The mean values of all the groups were significantly lower than control positive.

The results agreed with Bhathene et al.,(2002) they showed that, plasma triglyceride was reduced by $37 \%$ in rats fed flaxseed meal. These authors showed that, the defatted flaxseed reduced serum concentration of LDL cholesterol due to Alfa linolenic acid and soluble fiber, which may posses the mentioned effect. Generally, these data agree with those obtained by (Gaafar, 2005) who found that, LDL cholesterol decreased when hypercholesterolemic rats fed on cake content flaxseed. 


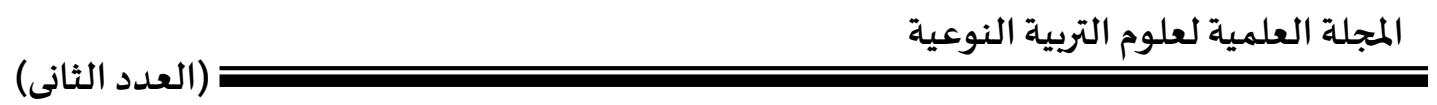

In addition to, Romero et al., (2002) suggested that Plantago ovata exerts its hypolipidemic effect by affecting bile acid absorption and altering hepatic cholesterol metabolism . Also, Moreno et al., (2003) showed that psyllium improves glucose homeostasis, the lipid and lipoprotein profile in hypercholesterolemic children.

Table (3) shows testing serum ALT, AST, ALP and GGT for control positive and different groups of hepatotoxicity rats fed on different concentration of seeds. It's clear that ALT and AST for control positive was higher than control negative.

It could be observed that all groups were significantly lower than the positive control and the group of $2.5 \%$ plantain has the best effect in improve serum AST. While the group of $2.5 \%$ mixture of all seeds was high significant $(p<0.01)$ when compared with control positive group.

Regarding Alkaline Phosphatase (ALP), the acticity of ALP enzyme increased significantly $(\mathrm{p}<0.05)$ in toxic rats as compared to the normal control group being( 295.55 and $255.47 \mathrm{IU} / \mathrm{L}$ ), respectively. While the tested groups feed with $7.5 \%$ mixture of all seeds. 5\% flaxseed, 5\% mixture of all seeds and $2.5 \%$ plantain have significant at $5 \%(\mathrm{P}<0.05)$ compared with positive control.

As regards the (GGT) activity, the highest improvement was $7.5 \%$ mixture of all seeds (48.45) being lowest was $2.5 \%$ flaxseed the values of serum ALT, AST, ALP and GGT were significantly decreased in all rats groups.

The results in table (3) agreed with those reported by Shakir and Madhusudhan(2007) who reported that of flaxseed chutney (15\%, w/w) resulted in depletion of serum marker enzymes and exhibited recoupment thus showing significant hepatoprotective effect. It was observed that flaxseed chutney supplemented diet could lower the serum cholesterol and as a potential source of antioxidants it could exert protection against hepatotoxic damage induced by carbon tetrachloride $(\mathrm{CCl} 4)$ in rats.

Table (4) showed that The effect of different diets supplement with flaxseed, plantain and mixture of all seeds on uric acid (UA), urea nitrogen (UN) and creatinine $(\mathrm{Cr})$ in serum of rats received CCL4 . Non significant difference was found between the toxic rats fed on $2.5 \%$ flaxseed, $2.5 \%$ plantain, $5 \%$ plantain and $7.5 \%$ mixture of all seeds in the concentration of uric acid, while these groups have decreased uric acid high significant at $(\mathrm{p}<0.01)$ compared to the positive control.

The rats fed with $7.5 \%$ mixture of all seeds had the best effect in decreasing urea level. On the other hand the groups of $2.5 \%$ flaxseed and $2.5 \%$ plantain non significantly the concentration of urea nitrogen compared to positive control.

Concerning creatinine, the concentration increased significantly $(\mathrm{p}<0.05)$ in the positive group, as compared to the negative control group $(0.80 \pm 0.042$ and 
$0.64 \pm 0.03)$, respectively. Meanwhile, no significant deference between experimental rats supplement by $2,5 \%$ flaxseed, $2.5 \%$ plantain and rats fed on $2.5 \%$ mixture of all seeds. At the end, it could be observed that the kidney function was reduced in the experimental rats fed with flaxseed, plantain and mixture of it. There was significant lower effect of kidney function on toxic control group.

The results were agreement with the result obtained by Gaafar (2005) who found that, hypercholesterolemic rats fed diet containing cakes were fortified with different levels of hulled flaxseed shown significant improvement of the renal function in comparison to hypercholesterolemic rats. Also agreed with Cabezas et al.,(2003) who observed that feeding HLA-B27 transgenic rats (8-10 weeks old) on a fiber-supplemented diet (5\% Plantago ovata seeds) for 13 weeks before evaluation of the colonic inflammatory status decreased some of the proinflammatory mediators involved in the inflammatory process: nitric oxide, leukotriene $\mathrm{B}(4)$, tumor necrosis factor alpha (TNFalpha).

Table (1): Effect of flaxseed, plantain and mixture of all seeds on Initial body weight, Final body weight, body weight gain, food intake and FER( feed efficiency ratio).

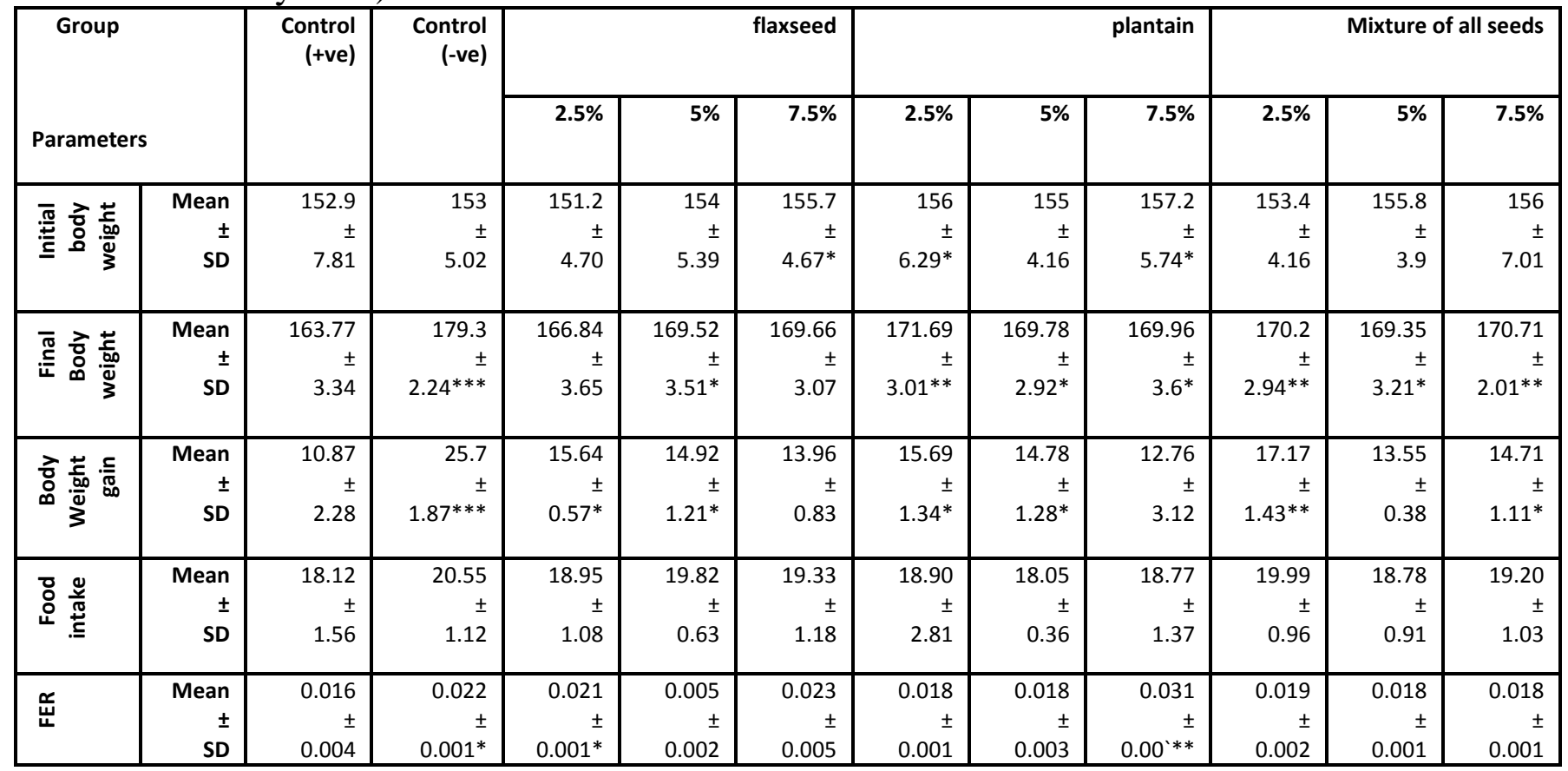

*Differences are significant at $5 \%(\mathbf{p}<0.05) . \quad * *$ Differences are high significant at $1 \%(p<0.01)$.

*** Differences are very high significant at $0.1 \%(\mathbf{p}<0.001)$. 
Control (-ve): rats fed on basal diet. Control (+ve): rats were pretreated with CCL4 and fed on basal diet.

Table (2): Effect of flaxseed, plantain and mixture of all seeds on Total cholesterol, Triglyceride and HDL, LDL and

VLDL of rats.

\begin{tabular}{|c|c|c|c|c|c|c|c|c|c|c|c|c|}
\hline \multirow{2}{*}{\multicolumn{2}{|c|}{ Group }} & \multirow{2}{*}{$\begin{array}{l}\text { Control } \\
\text { (+ve) }\end{array}$} & \multirow{2}{*}{$\begin{array}{l}\text { Control } \\
\text { (-ve) }\end{array}$} & \multicolumn{3}{|c|}{ flaxseed } & \multicolumn{3}{|c|}{ plantain } & \multicolumn{3}{|c|}{ Mixture of all seeds } \\
\hline & & & & $2.5 \%$ & $5 \%$ & $7.5 \%$ & $2.5 \%$ & $5 \%$ & $7.5 \%$ & $2.5 \%$ & $5 \%$ & $7.5 \%$ \\
\hline 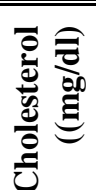 & $\begin{array}{r}\text { Mean } \\
\pm \\
\text { SD }\end{array}$ & $\begin{array}{l}116.33 \\
\pm \\
6.83\end{array}$ & $\begin{array}{l}88.91 \\
\pm \\
2.39 * *\end{array}$ & $\begin{array}{l}113.8 \\
3 \\
\pm \\
7.80\end{array}$ & $\begin{array}{l}111.8 \\
1 \\
\pm \\
8.04\end{array}$ & $\begin{array}{l}105.06 \\
\pm \\
4.31 *\end{array}$ & $\begin{array}{l}110.5 \\
8 \\
\pm \\
7.33\end{array}$ & $\begin{array}{l}101.8 \\
8 \\
\pm \\
9.29\end{array}$ & $\begin{array}{l}90.72 \\
\pm \\
3.7 * *\end{array}$ & $\begin{array}{l}102.5 \\
8 \\
\pm \\
9.11\end{array}$ & $\begin{array}{l}95.07 \\
\pm \\
3.96 *\end{array}$ & $\begin{array}{l}92.60 \\
\pm \\
4.54^{*}\end{array}$ \\
\hline 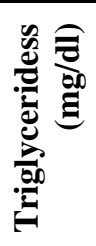 & $\begin{array}{r}\text { Mean } \\
\pm \\
\text { SD }\end{array}$ & $\begin{array}{l}100.55 \\
\pm \\
7.81\end{array}$ & $\begin{array}{l}84.23 \\
\pm \\
3.93^{* *}\end{array}$ & $\begin{array}{l}93.26 \\
\pm \\
1.62\end{array}$ & $\begin{array}{l}92.34 \\
\pm \\
1.65^{*}\end{array}$ & $\begin{array}{l}89.52 \\
\pm \\
3.06 *\end{array}$ & $\begin{array}{l}87.23 \\
\pm \\
4.03 * *\end{array}$ & $\begin{array}{l}93.16 \\
\pm \\
5.81^{*}\end{array}$ & $\begin{array}{l}93.23 \\
\pm \\
4.25^{*}\end{array}$ & $\begin{array}{l}95.23 \\
\pm \\
5.18\end{array}$ & $\begin{array}{l}94.23 \\
\pm \\
4.42^{*}\end{array}$ & $\begin{array}{l}93 \\
\pm \\
1.06^{*}\end{array}$ \\
\hline 司 & $\begin{array}{r}\text { Mean } \\
\pm \\
\text { SD }\end{array}$ & $\begin{array}{l}32.51 \\
\pm \\
6.48\end{array}$ & $\begin{array}{l}41.04 \\
\pm \\
1.57^{* *}\end{array}$ & $\begin{array}{l}34.54 \\
\pm \\
5.95\end{array}$ & $\begin{array}{l}38.64 \\
\pm \\
6.71^{*}\end{array}$ & $\begin{array}{l}39.05 \\
\pm \\
3.06 *\end{array}$ & $\begin{array}{l}38.68 \\
\pm \\
4.03 *\end{array}$ & $\begin{array}{l}34.69 \\
\pm \\
9.80\end{array}$ & $\begin{array}{l}38.62 \\
\pm \\
2.93^{*}\end{array}$ & $\begin{array}{l}33.71 \\
\pm \\
9.36\end{array}$ & $\begin{array}{l}33.80 \\
\pm \\
8.95\end{array}$ & $\begin{array}{l}38.12 \\
\pm \\
1.57^{* *}\end{array}$ \\
\hline 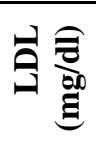 & $\begin{array}{r}\text { Mean } \\
\pm \\
\text { SD }\end{array}$ & $\begin{array}{l}62.55 \\
\pm \\
10.74\end{array}$ & $\begin{array}{l}46.07 \\
\pm \\
5.8^{* *}\end{array}$ & $\begin{array}{l}61.07 \\
\pm \\
8.24\end{array}$ & $\begin{array}{l}59.36 \\
\pm \\
9.92\end{array}$ & $\begin{array}{l}58.54 \\
\pm \\
4.35\end{array}$ & $\begin{array}{l}51.95 \\
\pm \\
4.68^{* *}\end{array}$ & $\begin{array}{l}55.76 \\
\pm \\
5.44^{*}\end{array}$ & $\begin{array}{l}56.49 \\
\pm \\
4.05^{*}\end{array}$ & $\begin{array}{l}51.96 \\
\pm \\
1.56 * *\end{array}$ & $\begin{array}{l}51.48 \\
\pm \\
1.20 * \\
*\end{array}$ & $\begin{array}{l}59.08 \\
\pm \\
3.54\end{array}$ \\
\hline$\vec{\nabla}$ & $\begin{array}{r}\text { Mean } \\
\pm \\
\text { SD }\end{array}$ & $\begin{array}{l}23.83 \\
\pm \\
5.18\end{array}$ & $\begin{array}{l}18.4 \\
\pm \\
4.27^{*}\end{array}$ & $\begin{array}{l}21.76 \\
\pm \\
3.05\end{array}$ & $\begin{array}{l}21.92 \\
\pm \\
3.60\end{array}$ & $\begin{array}{l}22.76 \\
\pm \\
3.47\end{array}$ & $\begin{array}{l}19.05 \\
\pm \\
3.42 *\end{array}$ & $\begin{array}{l}20.77 \\
\pm \\
2.36^{*}\end{array}$ & $\begin{array}{l}20.53 \\
\pm \\
2.1 *\end{array}$ & $\begin{array}{l}21.23 \\
\pm \\
3.20\end{array}$ & \begin{tabular}{|l}
21.22 \\
\pm \\
4.32
\end{tabular} & $\begin{array}{l}21 \\
\pm \\
2.21\end{array}$ \\
\hline
\end{tabular}

*Differences are significant at 5\% $(\mathbf{p}<0.05)$. ** Differences are high significant at $1 \%(\mathbf{p}<0.01)$.

**** Differences are very high significant at $0.1 \%(\mathbf{p}<0.001)$.

Control (-ve): rats fed on basal diet.

Control

(+ve): rats were pretreated with CCL4 and fed on basal diet. 
المجلة العلمية لعلوم التربية النوعية

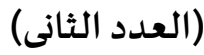

Table (3): Effect of flaxseed, plantain and mixture of all seeds on AST, ALT, ALP and GGT of rats.

\begin{tabular}{|c|c|c|c|c|c|c|c|c|c|c|c|c|}
\hline \multirow{2}{*}{\multicolumn{2}{|c|}{ up }} & \multirow{2}{*}{$\begin{array}{r}\text { Control } \\
\text { (+ve) }\end{array}$} & \multirow{2}{*}{$\begin{array}{r}\begin{array}{r}\text { Control } \\
\text { (-ve) }\end{array} \\
138.83\end{array}$} & \multicolumn{3}{|c|}{ flaxseed } & & \multirow{2}{*}{\multicolumn{2}{|c|}{$\begin{array}{r}\text { plantain } \\
7.5 \%\end{array}$}} & \multicolumn{3}{|c|}{ Mixture of all seeds } \\
\hline & & & & $2.5 \%$ & $5 \%$ & 7.5\% & $2.5 \%$ & & & $2.5 \%$ & $5 \%$ & 7.5\% \\
\hline 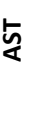 & $\begin{array}{r}\text { Mean } \\
\pm \\
\text { SD }\end{array}$ & $\begin{array}{r}190.96 \\
\pm \\
9.73\end{array}$ & $\begin{array}{r}138.83 \\
\pm \\
5.14 * * *\end{array}$ & $\begin{array}{r}182.5 \\
\pm \\
9.73^{*}\end{array}$ & $\begin{array}{r}175.7 \\
7 \\
\pm \\
8.23^{*}\end{array}$ & $\begin{array}{r}167.08 \\
\pm \\
5.82^{* *}\end{array}$ & $\begin{array}{r}150.20 \\
\pm \\
2.81^{* * *}\end{array}$ & $\begin{array}{r}162.89 \\
\pm \\
1.15^{* *}\end{array}$ & $\begin{array}{r}163.62 \\
\pm \\
3.87^{* *}\end{array}$ & $\begin{array}{r}182.6 \\
9 \\
\pm \\
9.47^{*}\end{array}$ & $\begin{array}{r}172.3 \\
1 \\
\pm \\
2.55^{*}\end{array}$ & $\begin{array}{r}160.96 \\
\pm \\
3.09 * *\end{array}$ \\
\hline 上 & $\begin{array}{r}\text { Mean } \\
\pm \\
\text { SD }\end{array}$ & $\begin{array}{r}195.32 \\
\pm \\
8.19\end{array}$ & $\begin{array}{r}144.31 \\
\pm \\
3.16^{* *}\end{array}$ & $\begin{array}{r}183.1 \\
2 \\
\pm \\
10.72\end{array}$ & $\begin{array}{r}172.3 \\
6 \\
\pm \\
4.41^{*}\end{array}$ & $\begin{array}{r}197.4 \\
\pm \\
25.80\end{array}$ & $\begin{array}{r}178.28 \\
\pm \\
5.31^{*}\end{array}$ & $\begin{array}{r}182.89 \\
\pm \\
9.80\end{array}$ & $\begin{array}{r}171.62 \\
\pm \\
4.51^{*}\end{array}$ & $\begin{array}{r}179.1 \\
6 \\
\pm \\
3.76^{*}\end{array}$ & $\begin{array}{r}189.4 \\
4 \\
\pm \\
9.6\end{array}$ & $\begin{array}{r}185 \\
\pm \\
8.75\end{array}$ \\
\hline$\frac{\varrho}{4}$ & $\begin{array}{r}\text { Mean } \\
\pm \\
\text { SD }\end{array}$ & $\begin{array}{r}295.55 \\
\pm \\
9.95\end{array}$ & $\begin{array}{r}255.47 \\
\pm \\
3.92^{* *}\end{array}$ & $\begin{array}{r}287.1 \\
4 \\
\pm \\
6.11\end{array}$ & $\begin{array}{r}271.1 \\
5 \\
\pm \\
5.25^{*}\end{array}$ & $\begin{array}{r}262.76 \\
\pm \\
3.11^{* *}\end{array}$ & $\begin{array}{r}279.09 \\
\pm \\
4.32 *\end{array}$ & $\begin{array}{r}291.66 \\
\pm \\
6.43\end{array}$ & $\begin{array}{r}266.17 \\
\pm \\
2.88^{* *}\end{array}$ & $\begin{array}{r}283.5 \\
5 \\
\pm \\
5.22\end{array}$ & $\begin{array}{r}273.3 \\
6 \\
\pm \\
5.93^{*}\end{array}$ & $\begin{array}{r}270.56 \\
\pm \\
6.12^{*}\end{array}$ \\
\hline 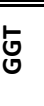 & $\begin{array}{r}\text { Mean } \\
\pm \\
\text { SD }\end{array}$ & $\begin{array}{r}70.28 \\
\pm \\
5.27\end{array}$ & $\begin{array}{r}42.31 \\
\pm \\
3.67^{* *}\end{array}$ & $\begin{array}{r}65.46 \\
\pm \\
9.50\end{array}$ & $\begin{array}{r}64.02 \\
\pm \\
8.35\end{array}$ & $\begin{array}{r}61.60 \\
\pm \\
2.68^{*}\end{array}$ & $\begin{array}{r}55.20 \\
\pm \\
1.25^{* *}\end{array}$ & $\begin{array}{r}67.05 \\
\pm \\
3.95\end{array}$ & $\begin{array}{r}64.54 \\
\pm \\
4.71\end{array}$ & $\begin{array}{r}63.31 \\
\pm \\
3.31 *\end{array}$ & $\begin{array}{r}54.02 \\
\pm \\
3.04^{*}\end{array}$ & $\begin{array}{r}48.45 \\
\pm \\
3.94 * *\end{array}$ \\
\hline
\end{tabular}

*Differences are significant at $5 \%(\mathbf{p}<0.05) . *$ Differences are high significant at $1 \%(p<0.01)$.

*** Differences are very high significant at $0.1 \%(\mathrm{p}<0.001)$.

Control (-ve): rats fed on basal diet.

Control

(+ve): rats were pretreated with CCL4 and fed on basal diet.

Table(4): Effect of flaxseed, plantain and mixture of all seeds on Uric acid, Urea and Creatinine of rats.

\begin{tabular}{|c|c|c|c|c|c|c|c|c|c|c|c|c|}
\hline \multirow{2}{*}{\multicolumn{2}{|c|}{ Grou }} & \multirow{2}{*}{$\begin{array}{r}\text { Control } \\
(+\mathrm{ve})\end{array}$} & \multirow{2}{*}{$\begin{array}{r}\text { Control } \\
\text { (-ve) }\end{array}$} & \multicolumn{3}{|r|}{ flaxseed } & \multicolumn{3}{|c|}{ plantain } & \multicolumn{3}{|c|}{ Mixture of all seeds } \\
\hline & & & & $2.5 \%$ & $5 \%$ & $7.5 \%$ & $2.5 \%$ & $5 \%$ & $7.5 \%$ & $2.5 \%$ & $5 \%$ & $7.5 \%$ \\
\hline 는 믐 & $\begin{array}{r}\text { Mean } \\
\pm \\
\text { SD }\end{array}$ & $\begin{array}{r}4.32 \\
\pm \\
0.880\end{array}$ & $\begin{array}{r}2.90 \\
\pm \\
0.12^{* *}\end{array}$ & $\begin{array}{r}3.52 \\
\pm \\
0.25^{* *}\end{array}$ & $\begin{array}{r}3.52 \\
\pm \\
0.51\end{array}$ & $\begin{array}{r}3.55 \\
\pm \\
0.99\end{array}$ & $\begin{array}{r}3.17 \\
\pm \\
0.18^{* *}\end{array}$ & $\begin{array}{r}3.15 \\
\pm \\
0.26^{* *}\end{array}$ & $\begin{array}{r}3.62 \\
\pm \\
1.14\end{array}$ & $\begin{array}{r}4.07 \\
\pm \\
1.17\end{array}$ & $\begin{array}{r}3.60 \\
\pm \\
1.06\end{array}$ & $\begin{array}{r}3.25 \\
\pm \\
0.06^{* *}\end{array}$ \\
\hline 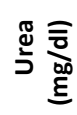 & $\begin{array}{r}\text { Mean } \\
\pm \\
\text { SD }\end{array}$ & $\begin{array}{r}53.63 \\
\pm \\
3.80\end{array}$ & $\begin{array}{r}33.13 \\
\pm \\
5.96^{* *}\end{array}$ & $\begin{array}{r}50.25 \\
\pm \\
1.70\end{array}$ & $\begin{array}{r}48.29 \\
\pm \\
6.45\end{array}$ & $\begin{array}{r}37.04 \\
\pm \\
1.98^{* *}\end{array}$ & $\begin{array}{r}44.917 \\
\pm \\
9.69\end{array}$ & $\begin{array}{r}40.63 \\
\pm \\
3.66^{* *}\end{array}$ & $\begin{array}{r}39.41 \\
\pm \\
2.52^{* *}\end{array}$ & $\begin{array}{r}47.15 \\
\pm \\
6.2\end{array}$ & $\begin{array}{r}44.12 \\
\pm \\
2.55^{*}\end{array}$ & $\begin{array}{r}37 \\
\pm \\
1.27^{* *}\end{array}$ \\
\hline 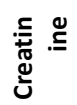 & $\begin{array}{r}\text { Mean } \\
\pm \\
\text { SD }\end{array}$ & $\begin{array}{r}0.807 \\
\pm \\
0.042\end{array}$ & $\begin{array}{r}0.64 \\
\pm \\
0.03^{* *}\end{array}$ & $\begin{array}{r}0.75 \\
\pm \\
0.05\end{array}$ & $\begin{array}{r}0.71 \\
\pm \\
0.11^{*}\end{array}$ & $\begin{array}{r}0.69 \\
\pm \\
0.10^{* *}\end{array}$ & $\begin{array}{r}0.78 \\
\pm \\
0.05\end{array}$ & $\begin{array}{r}0.78 \\
\pm \\
0.07\end{array}$ & $\begin{array}{r}0.70 \\
\pm \\
0.12^{*}\end{array}$ & $\begin{array}{r}0.78 \\
\pm \\
0.07\end{array}$ & $\begin{array}{r}0.70 \\
\pm \\
0.10^{*}\end{array}$ & $\begin{array}{r}0.691 \\
\pm \\
0.16^{* *}\end{array}$ \\
\hline
\end{tabular}

*Differences are significant at $5 \%(\mathbf{p}<0.05) . * *$ Differences are high significant at $1 \%(p<0.01)$.

**** Differences are very high significant at $0.1 \%(\mathrm{p}<0.001)$.

Control (-ve): rats fed on basal diet.

Control

(+ve): rats were pretreated with CCL4 and fed on basal diet. 


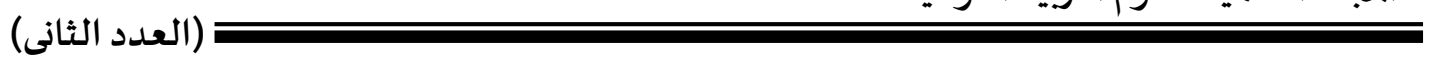

\section{REFERENCES}

Allain, C. C.(1974): Cholesterol enzymatic method. J. Clin. Chem.; 20:470.

Berglund, D. R. (2002): Flax: New Uses and Demands. In J. Janick \& A. Whipkey (Eds.), Trends in New Crops and New Uses, PP. 358-360. Alexandria, VA: ASHS Press.

Bhathena, S. J.; Ali, A. A.; Ali, I. M.; Carl, T. H. and Manuel, T. V.(2002): Differential effects of dietary flaxseed protein and soy protein on plasma triglyceride and uric acid levels in animal models. J.Nutr. Biochem.; 13: 684-689

Bloedon, L. T. and Szapary, P. O. (2004): Flaxseed and cardiovascular risk. Nut. Rev., 62: 18-27.

Cabezas,M.E.;Galvez, J.; Camuesco,D.; Lorente, M.D.; Concha, A.; Martine, O.; Redondo, L. and Zarzuelo,A. (2003): Intestinal antiinflammatory activity of dietery fiber (plantago ovata seeds ) in HLA-B27 transgenic rats. Clin Nut.Oct.; 22(5): 463-471.

Chatterjee, T. K. (2000): Medicinal Plants with Hepatoprotective Properties in Herbal Opinions, vol. III. Books and Allied (P) Ltd., Calcutta, 135.

Chapman,D.G.; Castilla, R. and Campell, J.A. (1959): "Evaluation of Protein in food. I. A method for the deterinination of portein efficiency ration". Can.J. Biochem. Phosiol., 37: 679-686.

Fassati, P. and Prencipe, L. (1982): Triglyceride enzymatic colorimatric method. J. Clin. Chem.; 28: 2077.

Gaafar, A. M. (2005): Production and evaluation of cake fortified by flaxseedas a functional food. Minufiya J. Agric. Res., 30: 1741-1756.

Jayasekhar, P. and Mohanan, P. V. (1997): Rathinam K. Hepatoprotective activity of ethyI acetate extate of Acacia catechu. Indian $\mathrm{J}$. Pharmacol.; 29: 426-428.

Karan, M.; Vasisht, K. and Handa, S.S.(1999): Antihepatotoxic activity of Swertia chirata on carbon tetrachloride-induced hepatotoxicity in rats. Phytotherapy Research, 13: 24-30.

Lee, R. and Nieman, D. (1996): Nutritional Assessment. $2^{\text {nd }}$ Ed., Mosby, Missouri, USA,; 591-594.

Lopez,M. F. (1977): HDL-cholesterol colorimetric method. J. Clin. Chem.; 230:282.

McCay, P. B.; Lai, E. K.; Poyer, J. L.; DuBose, C. M. and Janzen, E. G. (1984): Oxygen- and carbon-centered free radical formation during CCL4 metabolism: observation of lipid radicals in vivo and in vitro. J. Biol. Chem. 259: 2135-2143.

Moss, D.W. (1982): Alkaline Phosphates isoenzymes, Clin. Chem.; 28:20072016.

Moreno, L.A.; Tresaco, B.; Bueno, G.; Fleta, J.; Rodrguez, G.; Garagorri, J.M. and Bueno, M. (2003): Psyllium fiber and the metabolic control of obese children and adolescents. J Physiol. Biochem.; 59(3):235-242. 
Passmore, R. and Eastwood, M.N. (1986): Human nutrition and dietetics. Edinburgh: Churchill Livinstone, $8^{\text {th }}$ edn, : 18-19.

Petton, C. J. and Crouch, S. R. (1977): Enzymatic Determination of Urea. J. Anal. Chem.; 49: 464-469.

Recknagel, R. O. (1983): Carbon tetrachloride hepatotoxicity: status quo and future prospects. Trends Pharmacol. Sci.; 4: 129-131.

Recknagel, R. O. and Glende, E. A. (1973): Carbon tetrachloride hepatotoxicity: An example of lethal cleavage. CRC Cri. Rev. Toxicol.; 2:263-297.

Rocklin, Calif. (1996): Murray M. Encyclopedia of Nutritional Supplements. Prima Publishing.

Romero, A. L.; Rodriguez, O.G.; Yanez, Farias, G. A.;Barron, Hoyos, J. M. and Rayas, Duarte P.(2006): Chemical. Physicochemical, and Nutritional Evaluation of Plantago (Plantago ovata Forsk). Cereal. Chem.,83(4):358-362.

Romero, A.L.; West, K.L. Zern, T. and Fernandez, M.L. (2002): The seeds from plantago ovata lower plasma lipids by aitering hepatic and bile acid metabolism in guinea pigs. J. Nutr., 132(6): 1194-1198.

Shakir, k.A.F. and Madhusudhan, B. (2007): Hypocholesterolemic and Hepatoprotetive Effects of flaxseed. J. Clinical Biochemistry.; 22(1): 117-121.

Slater, T. F. (1984): Free radical mechanism in tissue injury. Biochem. J.; 222: $1-15$.

Snedecor, G. W. and Cocheran, W. C. (1980): Statistical Methods. 6 Ed., Iowa State University, Press.

Thefeld, W.; Hffmiester, H.; Busch, E.W.; Koller, P.U. and Volmer, J. (1974): Reference value for determination of GOT (glutamic opal acetic transaminase), GPT (glutamic pyruvic transaminase) and alkaline phosphatase in serum with optimal standard methods. Deut. Med. Wochencher, 99:343-351.

While, B. A.; Erickson, M. M. and Steven, S. C. (1970): Chemistry for Medical Theologies Ts. $3^{\text {rd }}$ Ed., C. v. Mosby company saint Louis, USA, : 662 .

Wolf, P. L. (1999): Biochemical diagnosis of liver diseases. Ind. J. Clin. Biochem.; 14:59-90. 